\title{
Vegetation restoration and organic matter accumulation on former agricultural lands in the boreal zone of Russia
}

\author{
S.V. Navalikhin ${ }^{1, *}$, D.A. Danilov ${ }^{1,3}, A . A$. Vaiman $^{3}$, and N.V. Galstyan ${ }^{2}$ \\ ${ }^{1}$ Saint-Petersburg State Forest Technical University named after S.M. Kirov, 194021 Saint-Petersburg, Russia \\ ${ }^{2}$ Voronezh State University of Forestry and Technologies named after G.F. Morozov, 394087 Voronezh, Russia \\ ${ }^{3}$ Leningrad Scientific Research Institute of Agriculture "BELOGORKA", 188338 Leningrad region, Russia
}

\begin{abstract}
This work investigates the influence of vegetation succession processes on the soil changes of former arable lands. It was noted that on post-agricultural soils, accumulation of organic matter in the soil differs, depending on the state of the land plot. The analysis shows that influence of vegetation on the accumulation of organic matter in the former arable horizon has a distinctly linear nature. The dominant species are mesotrophic and mesophyte plants, requiring little more than soils with mineral nutrients and sufficient humidity. The amount of organic matter accumulated in the upper horizon of the soil is greater than that of the underlying horizon. The content of organic matter in the soil horizons of the studied area is characterized by a distinct decreasing pattern in the direction from the forest edge to the field edge. Overall, it can be noted that farther away from the forest edge, the soils change from moderately acidic to slightly acidic. At this stage, depending on the succession state of the post-agricultural soil plot, the amount of organic matter in it is determined either by the species forming the soil cover and (or), to a greater extent, by tree and shrub vegetation. The optimum of the organic matter accumulation shifts to the zone with a large share of tree species.
\end{abstract}

\section{Introduction}

In present time, most regions of Russia have very diverse experimental data on organic carbon storage due to land use change of arable soils and vegetation restoration on them. [1,2]. According to modern ideas, soil organic matter is presented as an ecosystem component, a reserve but moderately dynamic energy pool, consisting from carbon and nutrients. It is a mass pool transformation product by consumers and reducing agents whose activities are controlled by the environment $[3,4]$.

In European countries, this issue is also relevant, which is reflected in a number of works [5-8]. For the boreal zone of the European part of Russia, a number of studies have been carried out on the succession processes impact on changes in the soil complex of former agricultural lands in different regions [1, 9-12].

Removal of arable land from active use usually creates the most favorable conditions for processes leading to an increase in organic carbon reserves in the soil: the amount of organic material supplied to it increases.

Postagrogenic lands in meadow ecosystem stage have a short closed cycle of organic matter circling, most part of which is from the root fraction. In forest biocenoses, most of the synthesized matter goes to form an increase in trunk and root wood mass, where it has been for years and decades.

In the tree stands, most dead plant part residues (leaf fall and tree waste) enter the soil surface, where they decompose, and their decomposition products are washed away by precipitation and re-enter the soil. Forest fall decomposes significantly slower than meadow. Forest fall degradation takes place with the release of acidic decomposition products. In meadow biocenoses, most dead plant input residues comes from roots, and their decomposition takes place in the soil at the formation site.

Postagrogenic areas at the meadow stage differ from forest areas not only by a larger mass waste, but also by high dispersion of plant residues, in the upper soil layer, by a higher nitrogen content, which contributes to their intensive decomposition and accelerated humification.

\section{Materials and methods}

The study aim was a comparative analysis of changes in the soil complex during the living ground cover and wood vegetation restoration.

The study object was a deposit section aged 20 years in the Luzhsky-Oredezhsky landscape of Leningrad region. The site area is about 8 hectares, the soils are swollen-loam well-cultivated, on a boulder red-colored loam. Previous agricultural use included active crop rotation. This soil type is most represented and

Corresponding author: 6423487@mail.ru 
economically developed in the research region. The site is adjacent to a ripe mixed tree stand with a preponderance of spruce and hardwood on the long and short side.

Three running lines were laid parallel to the longest side of the studied plot, each 50 meters from the adjacent forest edge. On each line, four 0.2 ha sites were defined to representatively cover the studied area. At these sites, $10 \mathrm{~m}^{2}$ circular plots were created to analyze the projective living ground cover and tree and shrub vegetation [13-15].

The projective living ground cover was calculated as $\%$ of the total experimental plot area, with a step of $5 \%$. Wood vegetation was accounted by species; the height of the species was measured. From each plot, 10 soil samples were taken, separately for the $0-20 \mathrm{~cm}$ and 20 $40 \mathrm{~cm}$ horizons. These samples were used to compile an average plot soil sample for each horizon. The organic matter content in the samples was measured by Tyurin method adapted for a photocolorimeter, the $\mathrm{pH}$ was determined by the potentiometric method [16-18].

\section{Results}

The soil samples agrochemical analysis showed that on the first running line, the $\mathrm{pH}$ changed slightly from low to higher, i.e. neutral soil acidity (Table 1) as it moved away from the forest wall. Thus, the $\mathrm{pH}(\mathrm{KCl})$ on the site located 40 meters from the forest wall is 4.74 , and on the farthest section, it is already 5.37. The $\mathrm{pH}$ values $(\mathrm{KCl})$ of the second and third experimental sites differ slightly from each other. In the upper horizons, the difference is 0.2 , in the lower horizons 0.4 units.

The $\mathrm{pH}(\mathrm{KCl})$ values on this line tend to increase the neutral response of the soil by the degree of distance from the ripe tree stand and vary between 4.5 and 5.1. When comparing the studied soil horizons, the underlying horizon has a more neutral reaction than the overlying one.

Table 1. $\mathrm{pHK}_{\mathrm{CL}}$ indicators at experimental facilities on postagrogenic soils

\begin{tabular}{|c|c|c|c|c|}
\hline \multirow[b]{2}{*}{$\begin{array}{l}\text { Plot } \\
\text { \#. }\end{array}$} & \multicolumn{4}{|c|}{$\mathrm{pH}_{\mathrm{KCl}}$} \\
\hline & $\begin{array}{l}\text { soil } \\
\text { horizon }\end{array}$ & $\begin{array}{l}1 \mathrm{st} \\
\text { running } \\
\text { line }\end{array}$ & $\begin{array}{l}\text { 2nd } \\
\text { running } \\
\text { line }\end{array}$ & $\begin{array}{l}3 \mathrm{~d} \\
\text { running } \\
\text { line }\end{array}$ \\
\hline \multirow{2}{*}{1} & $0-20$ & 4.74 & 4.65 & 5.52 \\
\hline & $20-40$ & 4.99 & 4.50 & 6.00 \\
\hline \multirow{2}{*}{2} & $0-20$ & 5.01 & 4.97 & 5.43 \\
\hline & $20-40$ & 5.01 & 5.08 & 5.01 \\
\hline \multirow{2}{*}{3} & $0-20$ & 4.82 & 5.09 & 5.08 \\
\hline & $20-40$ & 4.64 & 4.76 & 5.05 \\
\hline \multirow{2}{*}{4} & $0-20$ & 5.37 & 4.96 & 4.46 \\
\hline & $20-40$ & 6.67 & 4.69 & 4.42 \\
\hline
\end{tabular}

On the second running line, the $\mathrm{pH}(\mathrm{KCl})$ varies less across accounting sites depending on the distance of the tree stand and varies between 4.65 and 5.1. When comparing the studied horizons, in the lower lying horizon the $\mathrm{pH}(\mathrm{KCl})$ values are lower.

On the third running line, the $\mathrm{pH}$ index $(\mathrm{KCl})$ in the difference between the first and second line versions, when removed from the wall of the soil stand, gradually acquire a more acidic reaction, both in the upper horizon and in the lower horizon. In general, soil acidity decreases (from $\mathrm{pH}(\mathrm{KCl})$ 4.6-5.0 to $\mathrm{pH}$ (кCl) 5.1-5.5) with removal from the forest wall.

On the first running line, the content of organic matter when comparing the trial areas in removal process from a wall of a ripe forest stand, gradually decreases. The exception was made by plot 2 where the indication of $\mathrm{C}_{\text {org. }}$ makes $5.26 \%$ that in comparison with the site in 40 meters from the wood is $0.8 \%$ more (fig. 1-2). By soil analyses results consideration second running line, also, as well as on the first the regularity of decrease in percentage of organic matter at a distance from a wood wall is observed.

The carried-out organic matter analysis content $\left(\mathrm{C}_{\text {org. }}.\right)$ shows regularity on reduction of value at a distance from a forest stand (figure 1). The greatest stock of $\mathrm{C}_{\mathrm{org}}$ is recorded on the third running line.

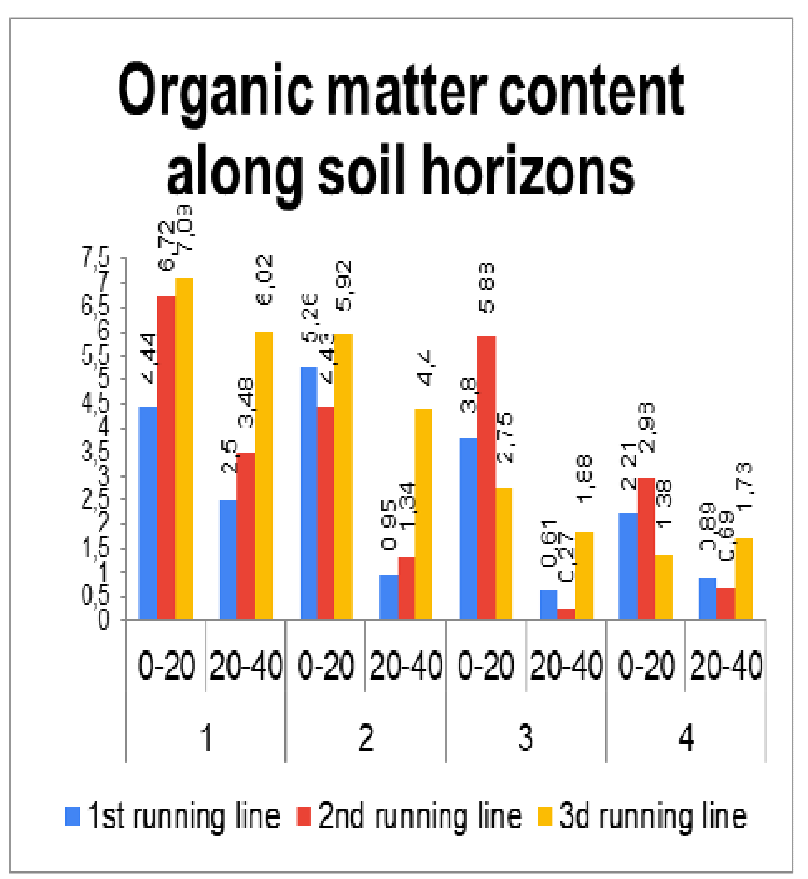

Fig. 1. Organic matter content along soil horizons

$\mathrm{C}_{\text {org }}$ variation in soil can be explained by the amount and species composition of vegetation.

The projective coating of the living ground cover (Figure 2) is dominated by two species Chamaenerion angustifolium (L.) and Solidago canadensis (L.). Of the complex colored species, Tarahasum officinale Wigg is present. In fact, on all accounting sites, and from the cereal mint of the Poa pratensis (L).and Elyrigia repens (L.). In general, dominant species refer to mesotrophes and mesophytes.

The largest number of views is 16 recorded on the third running line.

When considering the total projective living ground cover coating, a tendency can be observed that with its 
increase there is a content organic matter decrease in the in the soil (Figures 2 and 3).
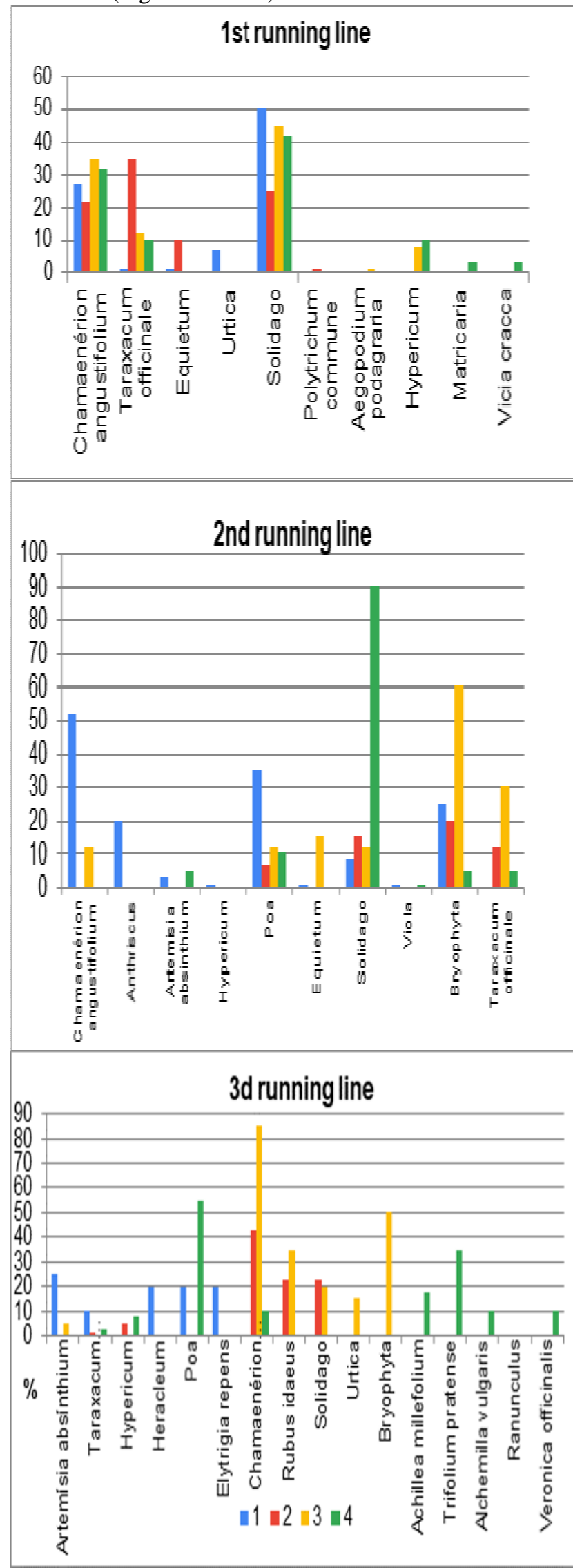

Fig. 2. Projective coating of vegetation species composition on running lines

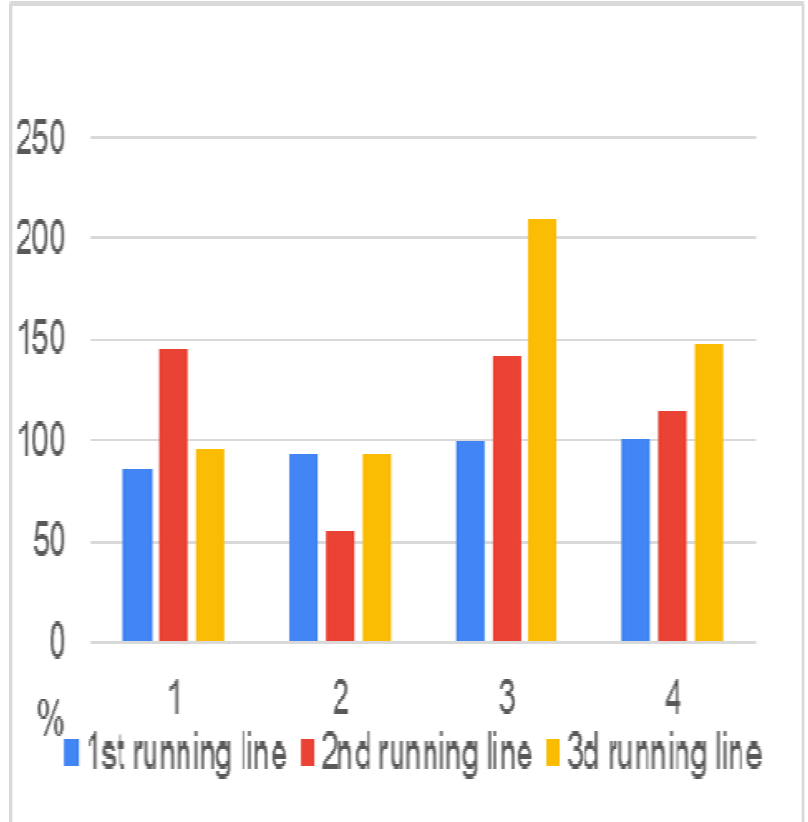

Fig. 3. Total vegetation covering on running lines

The analysis of vegetation influence on Corg accumulation in a soil layer of $0-40 \mathrm{~cm}$ shows linear dependence. The determination coefficient shows that the projective covering for $71 \%$ defines $\mathrm{C}$ org accumulation in soil (figure 4).

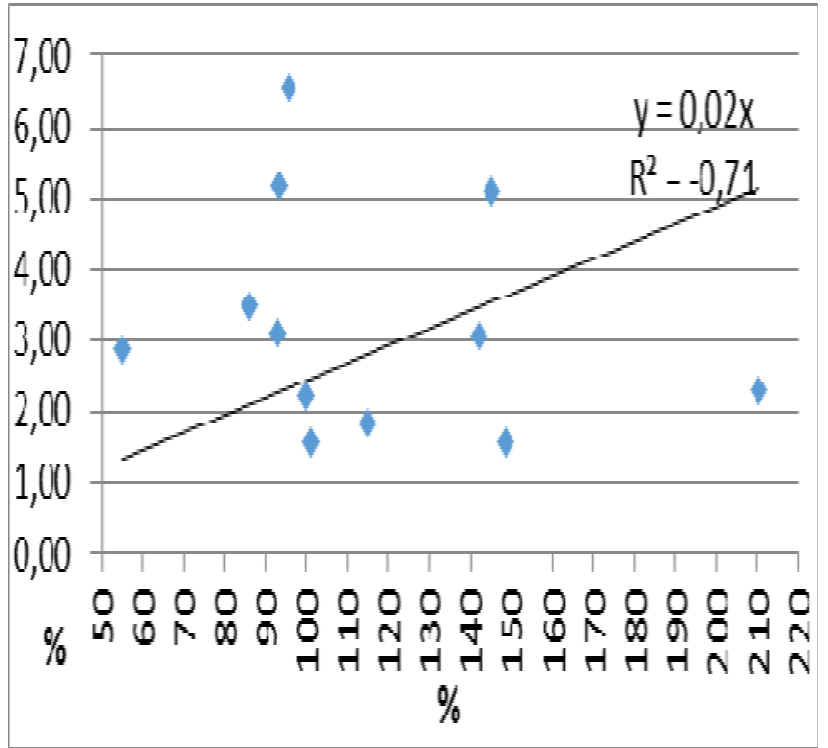

Fig. 4. Living ground cover effect on organic matter accumulation in the former arable soil horizon.

On the second running line, wood vegetation on the areas under study is mainly represented by hardwood species: willow (Salix L.), birch. The density of these species is up to 20 thousand copies, 1.5 to 5-6 m high (see Figure 5). Spruce, height from 1.5 to $2.5 \mathrm{~m}$, in the amount of 1- 2 thousand pieces per hectare mainly grows on test areas near the tree stand.

On the trial areas of the first running line there is an axis with a height of 1.5 meters, in the amount of 6 thousand copies per hectare. 
In the trial areas of the third running line, as on the first, there are the least amounts of wood vegetation. On test site \#2, willow up to 4-5 $\mathrm{m}$ high can be found, and on test site \#4 there is a spruce up to 1.5 meters high. The spruce placement is a curtain.

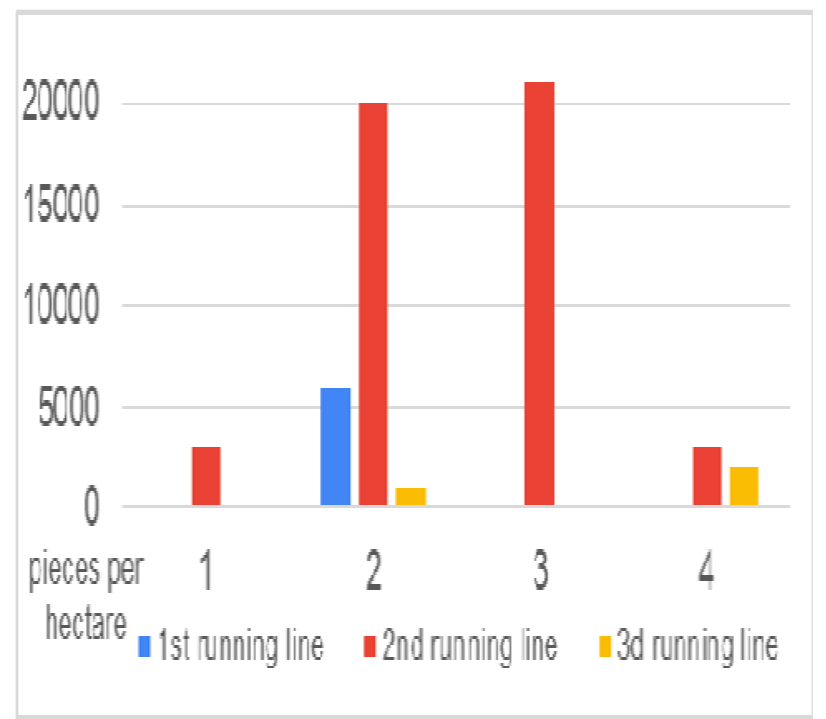

Fig. 5. Wood plants number on accounting sites on running lines

At present, wood-shrub level of different height is being formed at the investigated areas. The meadowruderal vegetation succession stage is being replaced by the stage of the small-scale tree stand, under the hemisphere or in the gastalins of which the resumption of spruce begins.

However, when introduced into these territories, ruderal plant species, in the absence of competition, can actively develop, forming large populations and transforming the environment into a favorable side and preventing the settlement of wood species.

The effect of wood vegetation and living ground cover on Corg 's stock is more evident on the central trial areas (TA) along the running lines (Figure 6). The optimum of organic matter accumulation is shifted to a zone with a large participation of wood species (Figure $5)$.

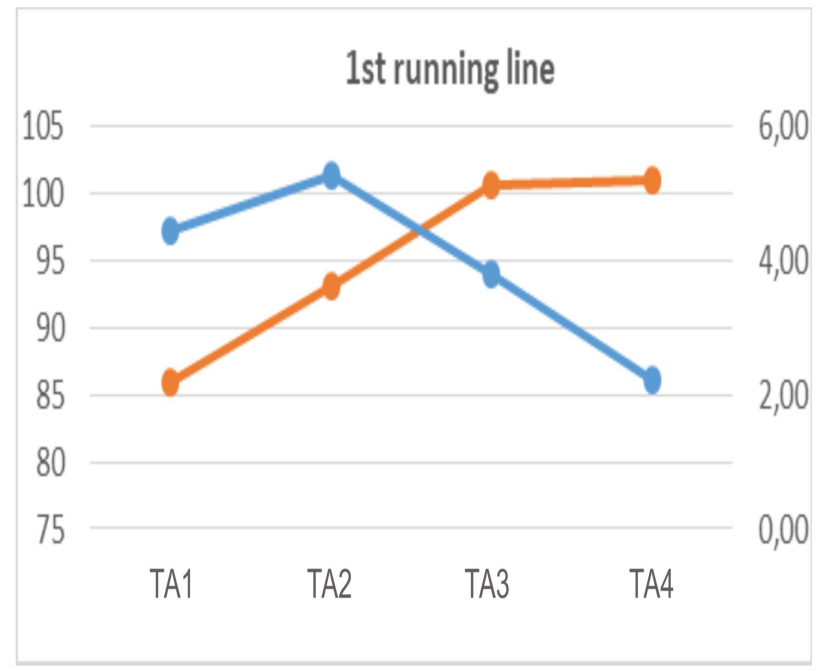

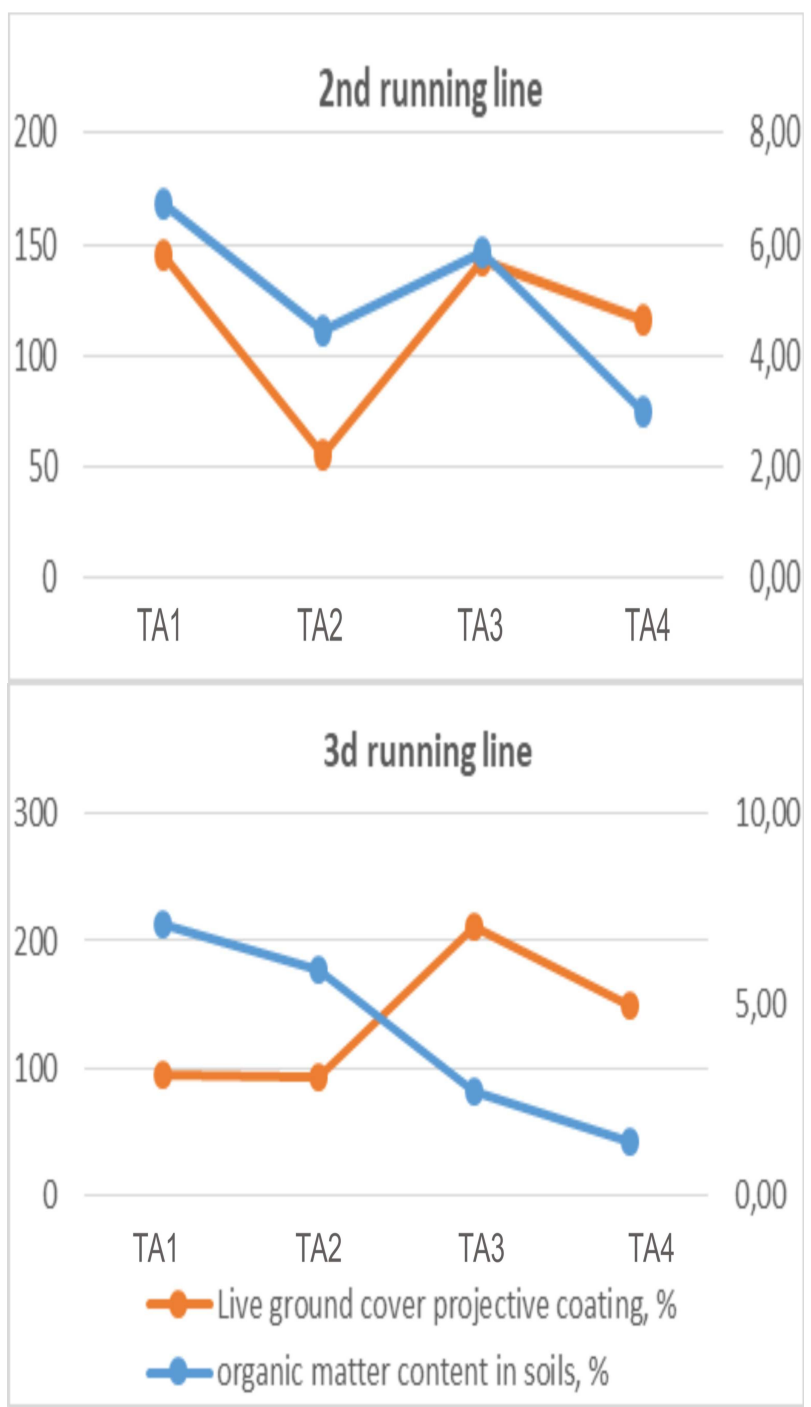

Fig. 6. Ratio live ground cover projective coating to organic matter content in soils

\section{Conclusion}

Thus, research results specify that during recovery succession there is an accumulation of organic matter in a soil complex more in the top 20-centimeter horizon.

Exchange acidity indicators of the soil tend to change towards neutral reaction from a wood wall to site border.

$\mathrm{C}_{\text {org }}$ indicators decrease with increased distance from a wood wall.

At this succession stage, the amount of organic matter is defined by specific structure of a live ground cover and wood and shrubby vegetation.

\section{References}

1. D.I. Lyury, S.V. Goryachkin, N.A. Karavaeva, The dynamics of agricultural lands in Russia in the 20th century and the postagrogenic restoration of vegetation and soils (GVOS, Moscow, 2010) $416 \mathrm{p}$.

2. Yu.I. Baeva, I.N. Kurganova, V.O. Lopez de Guerenu, V.M. Telesnina, Comparator assessment of carbon content in postagrogenic soils at different 
native climatic zones, PEMME, XX VIII(2), 29-39 (2017)

3. A.A. Romanovskaya, Organic carbon in long-fallow lands of Russia, Eurasian Soil Science, 39(1), 44-52 (2006)

4. A.V. Litvinovich, O.Yu. Pavlova, D.V. Chernov, Change of humus co-standing sod-podzolic soil at the termination of anthropogenic impact, Reports of the Russian Academy of Agricultural Sciences, 6, 26-28 (2002)

5. M.E. Bowena, C.A. McAlpineab, A.P.N. Housec, C.G. Smithd, Regrowth forests on abandoned agricultural land: A review of their habitat values for recovering forest fauna, Biological Conservation, 140, 3-4, 273-296 (2007)

6. D.A. Martens, T.E. Reedy, D.T. Lewis, Soil organic carbon content and composition of 130-year crop, pasture and forest land use managements, Global Change Biology, 10, 65-78 (2004)

7. C. Poeplau, A. Don, L. Vesterdal, J. Leifeld, B.A.S. Van Wesemael, J. Schumacher, A. Gensior, Temporal dynamics of soil organic carbon after land-use change in the temperate zone - carbon response functions as a model approach, Glob. Change Biol., 17, 2415-2427 (2011)

8. T.D. Hooker, J.E. Compton, Forest ecosystem carbon and nitrogen accumulation during the first century after agricultural abandonment, Ecol. Appl., 13(2), 299-313 (2003)

9. V.I. Melekhov, A.M. Antonov, D.V. Lokhov, Forestry potential of unused agricultural land, Bull. of the Pomeranian University, 3, 62-66 (2011)

10. N. Belyaeva, D. Danilov, S. Mandrykin, Restoration of spruce and pine in North West Russia, in:
Research for Rural Development 2019, Forestry and Wood Processing, 1, 131-138 (2019)

11. D.A. Danilov, S.S. Mandrykin, N.V. Belyaeva, A.A. Vaiman, Restoration of tree species on fallow lands of North-West Russia, IOP Conf. Series: Earth and Environmental Science, 316 (2019)

12. Report on the state and use of agricultural land in the Russian Federation in 2016 (Rosinformagrotech, Moscow, 2018) $240 \mathrm{p}$.

13. A.V. Gryazkin, Patent No. 2084129, Russian Federation, IPC C 6 A 01 G 23/00. A method of accounting regrowth No. 94022328/13 (July 20, 1997) Bulletin No. 20.

14. E.N. Andreeva et al., Methods for studying forest communities (Saint Petersburg Research institute of chemistry of Saint Petersburg State University, 2002) $240 \mathrm{p}$.

15. L.A. Zhukova et al., Ecological scales and methods of analysis of ecological diversity of plants (Mari State University, Yoshkar-Ola, 2010) 368 p.

16. V.G. Mineev, V.G. Sychev, G.P. Gamzikov, et al., Agrochemistry (Publishing house of the VNIIA named after D. N. Pryanishnikov, Moscow, 2017) $854 \mathrm{p}$.

17. L.V. Boytsova, E.Y. Regia, Determination of total organic carbon in sod-podzolic soil using oxidation and accounting methods released carbon dioxide, Agrophysics. Physics, Biophysics and ecology, 3(15), 20-27

18. M.P. Bankin, T.A. Bankina, L.P. Korobeynikova, Physical and chemical methods in agrochemistry and soil biology (Publishing house of St. Petersburg State University, 2005) 177 p. 